Jurnal Konstruksi Hukum | ISSN: 2746-5055

Vol. 2, No. 2, Mei $2021 \mathrm{Hal}$. 373-378| Tersedia online di

https://www.ejournal.warmadewa.ac.id/index.php/jukonhum

DOI: https://doi.org/10.22225/jkh.2.2.3258.373-378

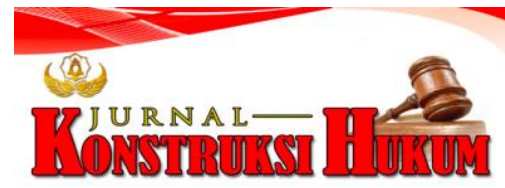

\title{
EFEKTIVITAS BANTUAN HUKUM ADVOKAT DI POS BANTUAN HUKUM (POSBAKUM) PENGADILAN NEGERI DENPASAR KELAS I A
}

\author{
Gregorius Yolan Setiawan, Anak Agung Sagung Laksmi Dewi, I Made Minggu Widyantara \\ Fakultas Hukum Universitas Warmadewa, Denpasar-Bali, Indonesia \\ gregoriussetiawan23@gmail.com, laksmidewii29@gmail.com, mademinggu21@gmail.com
}

\begin{abstract}
Abstrak
Perkembangan konsep Negara hukum merupakan produk dari sejarah, sebab rumusan atau pengertian Negara hukum itu terus berkembang mengikuti perkembangan sumber daya manusia. Negara berkewajiban memberikan bantuan hukum dengan tujuan melindungi serta mesejahterakan masyarakat hal ini sesuai dengan Pasal 27 ayat (1) undang-undang dasar negara republik Indonesia Tahun 1945, disebutkan semua warga Negara berkedudukan sama dihadapan hukum. Tujuan penelitian ini untuk menjelaskan kedudukan pos bantuan hukum (Posbakum) di Pengadilan Negeri Denpasar Kelas IA dalam memberikan bantuan hukum kepada terdakwa yang hukumannya di atas 5 Tahun dan mengetahui faktor-faktor kendala pos bantuan (Posbakum) di Pengadilan Negeri Denpasar. Penelitian ini didesain menggunakan penelitian hukum empiris denagn pendekatan perundang-undangan, selanjutnya sumber data yang digunakan adalah data primer dan sekunder. Adapun prosedur pengumpulan data dilakukan dengan wawan cara dan pencatatan yang selanjutnya dianalisis dengan cara deskriptif kualitatif. Hasil penelitian menunjukkan bahwa bantuan hukum yang diberikan oleh advokat pada pos bantuan hukum (Posbakum) di Pengadilan Negeri Denpasar Kelas I A sudah efektif karena telah melaksanakan pemberian hukum kepada masyarakat yang kurang mampu baik itu melalui penunjukan langsung oleh Hakim maupun melalui pengajuan surat tidak mampu dari masyarakat sesuai Undang-Undang No. 11 Tahun 2011 tentang Bantuan Hukum dan Sesuai MoU yang telah ditanda tangani antara Pengadilan Negeri Denpasar Kelas 1 A dengan pos bantuan hukum. Adapun faktor-faktor kendala yang sering dihadapi oleh pos bantuan (Posbakum) yaitu dari terdakwa itu sendiri yaitu keluarga dari terdakwa susah untuk ditemui untuk diminta surat keterangan tidak mampu dan masih rendahnya pengetahuan masyarakat mengenai fasilitas bantuan hukum.
\end{abstract}

Kata Kunci: Advokat, Bantuan Hukum, Pengadialan Negeri Denpasar

\begin{abstract}
The development of the concept of a rule of law is a product of history, because the formulation or definition of a rule of law is constantly developing in line with the development of human resources. The state is obliged to provide legal assistance with the aim of protecting and prospering the community, this is in accordance with Article 27 paragraph (1) of the 1945 constitution of the Republic of Indonesia, it is stated that all citizens are equal before the law. The purpose of this research is to explain the position of the legal aid post (Posbakum) in the Denpasar District Court Class IA in providing legal assistance to defendants whose sentence is over 5 years and to find out the factors of constraints for the assistance post (Posbakum) in the Denpasar District Court. This research is designed using empirical legal research with a statutory approach, then the data sources used are primary and secondary data. The data collection procedure was carried out by means of interviews and records, which were then analyzed using descriptive qualitative methods. The results showed that the legal assistance provided by lawyers at the legal aid post (Posbakum) at the Denpasar District Court Class IA was effective because it had carried out the provision of law to the underprivileged community either through direct appointment by the judge or through submission of a letter from the poor. according to Law No. 11 of 2011 concerning Legal Aid and in accordance with the MoU which was signed between the Denpasar District Court Class $1 \mathrm{~A}$ and the legal aid post. As for the factors that were often faced by the aid post (Posbakum), namely the defendant himself, namely that the family of the defendant was difficult to find to ask for a statement of incapacity and the community's low knowledge of legal aid facilities.
\end{abstract}

Keywords: Advocates, Legal Aid, Denpasar District Court

\section{PENDAHULUAN}

Pada dasarnya asas-asas hukum merupakan dasar pembenaran yang tak terbantahkan. Seorang tersangka harus dijadikan sebagai subjek hukum yang mempunyai martabat dan wajib dilindungi hakhaknya sebagai warga negara berdasarkan hak asasi manusia, sedangkan kesalahan tersangka 
ditempatkan sebagai objek hukum yang harus diadili oleh pengadilan selanjutnya putusan tersebut wajib dilaksanakan oleh tersangka (Bambang Tri Bawono, 2011). Tugas mulia Negara sebagai pimpina tertinggi adalah menjamin kesejahteraan seluruh warga Negara, perlindungan ini terutama dalam pemberian bantuan hukum kepada masyarakat. Bantuan hukum adalah jasa hukum yang diberikan kepada masyarakat oleh pemberi bantuan hukum (advokat) secara cuma-cuma cuam-cuma guna melindungi terdakwa dari ancaman

Dalam pemeriksaan tersangka, haknya perlindunagnnya telah dijamin oleh undang-undang yaitu perlindungan terhadap haknya untuk mempertahankan kebenaran dan pembelaan diri sesuai Bab VI, Pasal 50 sampai Pasal 68. Adapun hak tersangka yaitu hak untuk segera mendapat pemeriksaan oleh penyidik, hak untuk mengajukan agar perkaranya segera diajukan ke pengadilan dan hak untuk diberitahukan dengan jelas dalam bahasa yang dimengerti tentang apa yang disangkakan kepadanya pada waktu pemeriksaan. Ada beberapa tahap penyelidikan berdasarkan ketentua hukum acara pidana yaitu Tahap penyelidikan yang dilakukan oleh polisi Negara, Tahap penuntutan yang dilakukan oleh jaksa atau Penuntut Umum, Tahap pemeriksaan di depan sidang pengadilan oleh jaksa, selanjutnay tahap pelaksanaan putusan pengadilan oleh jaksa dan lembaga pemasyarakatan di bawah pengawasan ketua pengadilan yang bersangkutan (Samadi, 2015)

Untuk membuktikan benar atau salahnya tersangka, para tersangka berhak mendapat bantuan hukum pada setiap tingkat pemeriksaan. Tersangka diberi kewenangan menentukkan penasihat hukum yang disukainya. Bantuan hukum ini merupakan jarminan yang diberikan oleh Negara sebagai bentuk perlindungan hak terhadap warga Negara (Ramdan, 2014). Bahkan untuk menjamin terpenuhinya hak dalam mendapatkan bantuan hukum ini, Negara mewajibkan semua pejabat yang berwenang untuk menunjuk penasihat hukum secara cum-uma bagi tersangka apabila ia tidak mampu menyediakan penasihat hukumnya sendiri. Bantuan hukum yang diberikan oleh penasihat hukum kepada tersangka (advokat) dalam hal ini bukan berarti membela atau melindungi tersangka dari perbuatanya namun disini bantuan hukum mendampingi tersangka dalam menyampaikan kebenaran hukum atau dalil-dalil hukum tersangka mulai dari tahap penyelidikan sampai ketahap persidangan.

Penelitian terdahulu mengungkapkan faktor yang membuat kurang efektif dan efesiennya posbakum sebagai pemberi layanan hukum dengan baik pada perkara pidana di pengadilan Negeri yaitu tersendatnya pencairan dana atau anggaran untuk pengadaan pos bantuan hukum dan tidak lengkapnya sarana dan prasarana yang mendukung pemberian layanan hukum. Hal ini membuat masyarakat kesulitan mendapatkan petugas posbakum (Rajagukguk, 2016); dan (Prabowo, 2017). Selanjutnya menurut Fauzi \& Ningtyas, (2018) Penghambat terwujudnya access to law and justice bagi rakyat miskin ada lima yaitu kerangka hukum normatif yang tidak bekerja, kurangnya kesadaran hukum mengenai bantuan hukum, akses menuju peradilan yang bersifat formalitas, diskriminasi dan prosedur yang rumit dalam pendanaan bantuan hukum dan belum adanya pengawasan dalam penerapan pemberian bantuan hukum. Sampai saat ini di Indonesia sendiri diketahui bahwa bantuan hukum masih prioritas para tersangka dalam memperoleh perlindungan hukum, sehingga ada beberapa advokat dalam pemberian bantuan hukum meminta biaya sesuai kesepakatan. Oleh karena itu penelitian ini bertujuan untuk menjelaskan kedudukan pos bantuan hukum (Posbakum) di Pengadilan Negeri Denpasar Kelas IA dalam memberikan bantuan hukum kepada terdakwa yang hukumannya di atas 5 Tahun dan mengetahui faktor-faktor kendala memperoleh Pos Bantuan (Posbakum) di Pengadilan Negeri Denpasar

\section{METODE PENELITIAN}

Jenis penelitian ini adalah penelitian hukum empiris, yaitu penelitian yang berfokus pada data-data lapangan sebagai sumber data utama, seperti hasil wawancara dan observasi. Penelitian empiris digunakan untuk menganalisis hukum yang dilihat sebagai perilaku masyarakat yang berpola dalam kehidupan masyarakat yang selalu berinteraksi dan berhubungan dalam aspek kemasyarakatan. Sumber data yang digunakan adalah data primer dan sekunder. Adapun prosedur pengumpulan data dilakukan dengan wawan cara dan pencatatan yang selanjutnya dianalisis dengan cara deskriptif (Sugiyono, 2013) 


\section{HASIL DAN PEMBAHASAN}

\section{Kedudukan Posbakum di Pengadilan Negeri Denpasar Kelas I A dalam Memberikan Bantuan Hukum Kepada Terdakwa yang Hukumannya di Atas 5 Tahun}

Umunya diketahui bahwa seorang tersangka harus dijadikan sebagai subjek hukum yang mempunyai martabat, sedangkan kesalahan tersangka ditempatkan sebagai objek hukum. Prinsip ini disebut prinsip akusatur. Konsekuensi nyata dari prinsip akusatur adalah pengakuan terhadap asas praduga tak bersalah artinya seorang tersangka harus dianggap tidak bersalah sampai dibuktikan bersalah oleh pengadilan. Dalam proses rnembuktikan ada tidaknya kesalahan, seorang tersangka berhak mendapat bantuan hukum pada setiap tingkat pemeriksaan Lilik Mulyadi (2019). Seorang tersangka dapat memilih sendiri penasihat hukum yang disukainya. Bantuan hukum ini merupakan jaminan yang diberikan oleh Negara sebagai bentuk perlindungan hak terhadap warga Negara. Bahkan guna menjamin terpenuhinya hak mendapat bantuan hukum ini, Negara mewajibkan semua pejabat yang berwenang untuk menunjuk penasihat hukum secara Cuma-cuma bagi tersangka apabila tersangka tidak mampu menyediakan penasihat hukumnya sendiri (Apriansyah, 2020).

Terlepas dari kerancuan pengertian bantuan hukum di atas, tersimpan harapan yang besar akan terwujudnya keadilan yang tidak memihak. Tak peduli apakah orang tersebut mampu atau tidak, menggunakan jasa legal atau legal assistance, keadilan harus tetap ditegakkan agar hukum dapat memiliki kekuatan supremasi hukum di mata masyarakat. Karena bukan subjek hukumnya yang harus dihormati, tetapi hukum dan keadilan itu sendiri, karena bantuan hukum adalah suatu konsep untuk mewujudkan persamaan di hadapan hukum dan pemberian jasa hukum serta pembelaan bagi semua orang dalam kerangka keadilan untuk semua orang.

Kedudukan Pos Bantuan Hukum (Posbakum) yang berada di lingkungan Pengadilan Negeri Denpasar kelas I A menurut ibu Desi Pumarni Ketua Pos Bantuan Hukum Pengadilan Negeri Denpasar Kekas I A yaitu mernberikan bantuan hukum dalam bentuk pendampingan di persidangan bagi terdakwa yang ancaman hukuman 5 tahun ke atas dari awal dimulainya persidangan sampai didapatkannya putusan hakim. Selain bantuan hukurn dalam bentuk pendampingan di persidangan juga memberikan bantuan hukum non litigasi berupa konsultasi drafting dan lainnya.

Sifat bantuan hukum dari Pos Bantuan hukum hanya sampai tingkat pertama dan untuk tingkat selanjutnya yaitu tingkat banding, kasas dan peninjauan kembali, Pos Bantuan Hukum tidak bisa memberikan bantuan hukum secara cuma-cuma lagi dan apabila orang tersebut masih ingin menggirimkan jasa dari Pos Bantuan Hukum dalam bentuk pendampingan dipersidangan maka harus ada surat kuasa dan harus mengeluarkan dana sendiri. Semestinya Pos Bantuan Hukum Sejahtera harus memberikan jasa bantuan hukum berupa pendampingan dipersidangan harus memberikan bantuan hukum bagi terdakwa sampai didapatkannya putusan dan untuk mendapat kuasa dari terdakwa yang tidak mampu oleh Pos Bantuan Hukum rnelalui penunjukan dari Hakim yang menangangi perkara tersebut dan yang mendapatkan pendampingan dari posbakum hanya bagi terdakwa yang hukumannya di atas 5 tahun yang mempunyai kekuatan hukum tetap dan sesuai dengan keadilan karena di dalam Undang-Undang Dasar Negara Republik Indonesia Tahun 1945 Pasal 280 ayat (I) menyatakan bahwa setiap orang berhak atas pengakuan, jaminan, perlindungan dan kepastian hukum yang adil serta perlakuan yang sama di hadapan hukum. Untuk terdakwa yang ancaman hukuman 5 tahun ke bawah jika ingin menggunakan jasa bantuan hukum berupa pendampingan di persidangan oleh Pos Bantuan Hukum terkadang masih menggunakan surat kuasa dan bagi terdakwa tersebut harus mengeluarkan dana. Semestinya terdakwa yang ancaman hukuman 5 tahun ke bawah mendapatkan bantuan hukum secara curna-cuma karena di dalam Pasal 1 ayat (1) Undang-undang Nomor 16 Tahun 2011 tentang Bantuan Hukum Penyelenggaraan pemberian bantuan hukum yang diberikan kepada penerima bantuan hukum merupakan upaya untuk mewujudkan hakhaknya dan sekaligus sebagai implementasi Negara hukum yang mengakui dan melindungi serta menjamin hak asasi warga Negara akan kebutuhan akses terhadap keadilan (access to justicevie kesamaan di hadapan hukum (equality before the law).

Bantuan hukum merupakan pelayanan hukum (legal service) yang bertujuan untuk memberikan perlindungan hukum dan pembelaan terhadap hak-hak asasi tersangka atau terdakwa sejak ditahan sampai diperolehnya putusan pengadilan yang tetap. Perlindungan hukum bukan kesalahan tersangka atau terdakwa melainkan hak asasi tersangka atau terdakwa agar terhindar dari perlakuan dan tindakan tidak terpuji atau tindakan sewenang-wenang dari aparat penegak hukum. Adanya Pos Bantuan Hukum DPC peradi Denpasar di Pengadilan negeri Denpasar kelas IA, merupakan wujud 
tanggung jawab Negara kepada setiap orang dalam mencari keadilan hukum. Untuk terdakwa yang ancaman hukuman 5 tahun keatas maka Negara secara otomatis menunjuk penasihat hukum bagi mereka, Pasal 56 ayat (1) Undang-undang Nomor 8 Tahun 1981 tentang Kitab Undang-undang Hukum Acara Pidana menyatakan bahwa dalam hal tersangka atau terdakwa disangka atau didakwa melakukan tindak pidana yang diancam dengan pidana mati atau ancaman pidana lima belas tahun atau lebih atau bagi mereka yang tidak mampu yang diancam dengan pidana lima tahun atau lebih yang tidak mempunyai penasihat hukum sendiri, pejabat yang bersangkutan pada semua tingkat pemeriksaan dalam proses peradilan wajib menunjuk penasihat hukum bagi mereka.

Jika pos bantuan hukum tidak memiliki memory of understanding (MoU) atau nota kesepahaman dengan Pengadilan Negeri Denpasar, maka saat di persidangan hakim tidak akan menunjuk para advokat dari Pos Bantuan Hukum dalam memberikan bantuan hukum dalam bentuk pendampingan di persidangan terhadap terdakwa. Dalam pemberian bantuan hukum, tidak menargetkan perkara pertahun karena menunggu pcnunjukan oleh hakim. Dalam waktu 2 tahun belakangan ini yaitu tahun 2019 dan 2020 Pos bantuan hukum sudah memberikan bantuan hukum sudah menangani 1.362 perkara selama 2 tahun, dengan rincian 2019 non litigasi: 99 kasus dan litigasi: 595 kasus dan Tahun 2020 non litigasi: 114 kasus dan Litigasi:554 kasus. Selama pendampingan dan bantuan hukum yang diberikan oleh pos bantuan hukum, sekitar 90\% pendampingan dan bantuan hukum terhadap terdakwa mendapat putusan di bawah tuntutan jaksa, bahkan ada beberapa orang yang divonis bebas (hasil wawancara kepada petugas pos bantuan hukum).

Pelaksanaan pemberi bantuan bantuan hukum untuk masyarakat semua diatur dalam Pasal 8 ayat ( I) Undang-Undang Nomor 16 Tahun 2011 tentang Bantuan Hukum bahwa syarat-syarat Pemberi Bantuan Hukum sebagaimana dimaksud pada ayat (I) meliputi:

a. Berbadan hukum

b. Terakreditasi berdasarkan undang-undang ini

c. Memiliki kantor dan sekretariat yang tetap

d. Memiliki pengurus dan

e. Memiliki program bantuan hukum.

Adapun dalam pelaksanaan layanan hukum bagi masyarakat tidak mampu di Pengadilan Negeri Denpasar 1A oleh pos bantuan hukum, terdapat ketentuan-ketentuan yang berlaku umum untuk layanan pembebasan biaya yang diatur dalam Peraturan Mahkamah Agung (PERMA) Nomor 1 Tahun 2014 oleh direktorat jenderal badan peradilan umum (badilum). Setiap orang atau sekelompok orang yang tidak mampu secara ekonomi dapat mengajukan permohonan layanan bantuan hukum ke pos bantuan hukum dengan melampirkan dokumensebagai berikut:

1. Surat keterangan tidak mampu (SKTM) yang dikeluarkan oleh kepala Desa/ lurah

2. Surat keterangan tunjangan sosial lainnya seperti kartu keluarga miskin (KKM), kartu jaminan kesehatan masyarakat (jamkesmas), kartu beras miskin (Raskin), kartu program keluarga harapan (PKH), kartu bantuan langsung tunai (BLT), kartu perlindungan sosial (KPS)

3. Dokumen lainnya yang berkaitan dengan daftar penduduk miskin dalam basis data terpadu pemerintah atau yang dikeluarkan oleh instansi lain yang berwenang untuk memberikan keterangan tidak mampu.

Setelah persyaratan seseorang atau kelompok telah terpenuhi, maka pos bantuan hukum akan rnemberikan bantuan hukum berupa pendampingan dari awal dimulainya persidangan sampai didapatkannya putusan hakim, asalkan pihak yang membutuhkan bantuan hukum tersebut memang benar meminta dan mengajukan permohonan bantuan hukum ke pos bantuan hukum. Semestinya pemberian bantuan hukum berupa pendampingan di persidangan yang benar-benar rill dalam hukum tidak mesti hanya diberikan untuk terdakwa yang ancaman hukuman 5 tahun ke atas, akan tetapi untuk terdakwa yang ancaman hukuman 5 tahun ke bawah juga harus mendapatkan jasa bantuan hukum berupa pendampingan di persidangan yang benar-benar rill dalam hukum karena itu merupakan hak terdakwa yang harus dipenuhi

\section{Hambatan Pelayanan Bantuan Hukum Pada Pos Bantuan}

Hambatan yang ditemui dalam pelayanan pembcrian bantuan hukum pada pos bantuan hukum di Pengadilan Negeri Denpasar Kelas IA sebagai upaya menjamin hak dalam menyelesaikan perkara adalah terletak kepada pihak yang ingin memperoleh bantuan hukum secara prodeo tersebut tidak 
mengetahui hak dan kewajiban sebagai seorang yang membutuhkan pelayanan bantuan hukum. Masyarakat yang membutuhkan bantuan hukum tidak mempunyai pengetahuan untuk memperoleh bantuan hukum secara prodeo, sehingga terhambat juga pemberian bantuan hukum secara prodeo di Pengadilan Negeri Denpasar Kelas IA. Jalan keluar dari hambatan tersebut dengan memenuhi terlebih dahulu syarat yang akan diajukan, demi kelancaran proses untuk memperoleh bantuan hukum secara prodeo oleh pos bantuan hukum sebagai upaya menjamin hak dalam menyelesaikan perkara di Pengadilan Negeri Denpasar Kelas I A.

Undang-Undang Dasar 1945 Pasal 28 D ayat 1 menyebutkan bahwa setiap orang berhak atas pengakuan, jaminan perlindungan dan kepastian atas dasar inilah kemudian Negara memberikan jaminan kepada orang atau kelompok untuk memperoleh hak bantuan hukum sebagaimana tercanturn dalam Pasal 2 huruf b undang-undang Nomor 16 Tahun 2011 yaitu adanya asas persamaan kedudukan di dalam hukum. Konsep orang miskin Menurut Undang-Undang Nomor 16 Tahun 2011 tentang Bantuan Hukum yaitu setiap orang atau sekelompok orang yang tidak dapat memenuhi hak dasar secara layak dan mandiri. Adapun yang dimaksud dengan hak dasar dalam undang-undang yaitu hak atas pangan, sandang, layanan kesehatan, layanan pendidikan, pekerjaan dan berusaha atau perumahan (Caecilia \& Sondakh, 2014). Sebagaimana telah kita ketahui bersama dalam uraian sebelumnya, bahwa hingga saat ini, pelaksanaan pemberian bantuan hukum di Pengadilan Negeri Denpasar Kelas I A belum berjalan secara efektif dikarenakan beberapa faktor, baik internal maupun eksternal. Sebagai langkah perbaikan dalam rangka peningkatan kualitas pemberian bantuan hukum, diperlukan suatu upaya untuk meningkatkan efektifitas organisasi bantuan hukum dalam rangka pemberian bantuan hukum kepada orang atau kelompok.

Menurut Desi Purnarni Penasihat Hukum yang juga sebagai ketua pusat bantuan hukum di Pengadilan Negeri Denpasar Kelas IA, faktor-fakto yang menjadi kendala yang dihadapi oleh Lembaga Bantuan Hukum dalam memberikan bantuan hukum salah satunya ialah faktor substansi hukum. Desi menyatakan bahwa, undang-undang yang mengatur mengenai bantuan hukum, salah satunya yakni Undang- Undang Nomor 16 Tahun 2011 tentang Bantuan Hukum masih mengandung kelemahan-kelernahan. Dalam undang-undang ini, penerima bantuan hukum yang hanya ditujukan kepada orang atau kelompok orang miskin, perlu dikembangkan lagi. Pengaturan mengenai pendanaan dalam undang-undang ini juga perlu dikaji kembali, Mekanisme pelaporan yang harus dilakukan untuk mendapatkan anggaran bantuan hukum (pendanaan) juga menyulitkan harus menempuh veriflkasi, akreditasi yang melalui proses panjang yang kurang efisien tidak mampu sangat diperlukan, dan diharapkan adanya peningkatan atau intensitas pelaksanaan bantuan hukum dari tahun ke tahun. Didalam KUHAP, secara limitatif sudah ditegaskan, terhadap masyarakat kurang mampu, Negara menyediakan bantuan hukum dalam setiap tingkatan, dimulai dari penyidikan, penuntutan dan proses dimuka persidangan.

Bantuan hukum yang diberikan merupakan bentuk penghormatan HAM oleh negara setiap warga negara yang kurang mampu (Wadi, 2010). Didalam lapangan, lazim digunakan istilah "prodeo". Dalam istilah lain, seringjuga digunakan istilah "probono". Meningkatkan ketersediaan Pemberi Bantuan Hukum bagi tersangka yang tidak mampu (miskin) dalam rangka meningkatkan ketersediaan Pemberi Bantuan Hukum terhadap tersangka yang tidak mampu (miskin) yakni, meningkatkan koordinasi antara kepolisian dengan lembaga bantuan hukum. Dengan melakukan kerjasama ini, maka kebutuhan pemberi bantuan hukum untuk mendampingi tersangka yang tidak mampu (miskin) terpenuhi dan menjadi seimbang. Meningkatkan koordinasi dengan lembaga bantuan hukum juga telah dilakukan dengan cara melakukan komunikasi mengenai bantuan hukum gratis bagi masyarakat yang miskin. Salah satu caranya yaitu mensosialisasikan undang-undang Nomor 16 Tahun 2011 tentang Bantuan Hukum kepada aparat penegak dan penasehat hukum.

\section{SIMPULAN DAN SARAN}

\section{Simpulan}

Berdasarkan hasil analisis data, dapat disimpulkan bahwa kedudukan pos bantuan hukum (Posbakum) pada Pengadilan Negeri Denpasar Kelas I A dalam memberikan bantuan hukum kepada terdakwa yang hukumannya di atas 5 Tahun dan penunjukan langsung oleh Hakim yang menangani perkara tersebut hanya sampai tingkat pertama dan untuk tingkat selanjutnya yaitu tingkat banding, kasasi dan peninjauan kembali, pos bantuan hukum (Posbakum) pada Pengadilan Negeri Denpasar Kelas I A tidak bisa memberikan bantuan hukum secara cuma-cuma lagi dan apabila orang tersebut masih ingin 
menggunakan jasa dari Pos Bantuan (Posbakum) dalam bentuk pendampingan di persidangan maka harus ada surat kuasa dan harus mengeluarkan dana. Bantuan hukum yang di berikan oleh advokat pada pos bantuan hukum (Posbakum) di Pengadilan Negeri Denpasar Kelas I A sudah Evektif karena telah melaksanakan pemberian hukum kepada masyarakat yang kurang mampu baik itu melalui penunjukan langsung oleh Hakim maupun melalui pengajuan surat tidak mampu dari masyarakat kepada Pos Bantuan Hukum (Posbakum) Pengadilan Negeri Denpasar Kelas I A juga telah berjalan sesuai kentuan Undang-Undang No. 11 Tahun 2011 tentang Bantuan Hukum dan sesuai MoU yang telah di tanda tangani antara Pengadilan Negeri Denpasar Kelas I A dengan Pos Bantuan Hukum. Adapun faktor-faktor kendala yang sering dihadapi oleh Pos Bantuan (Posbakum) yaitu dari terdakwa itu sendiri, yaitu keluarga dari terdakwa susah untuk ditemui untuk diminta surat keterangan tidak mampu, selain dari pada itu umumnya kendala yang dihadapi oleh pos bantuan hukum dalam pelaksanaan pemberian jasa bantuan hukum yaitu masih rendahnya pengetahuan masyarakat mengenai fasilitas bantuan hukum.

\section{Saran}

Dari hasil penelitian di atas, adapun saran yaitu diharapkan kepada Pengadilan Negeri perlu meningkatkan sosialisasi pos bantuan hukum ini kepada masyarakat luas, agar masyarakat menjadi lebih tahu jika Pengadilan Negeri mempunyai pos bantuan hukum yang memberikan bantuan hukum secara cuma-cuma kepada masyarakat, sehingga diharapkan masyarakat tidak akan kesulitan jika ingin mengurus urusan perkara pidana ke Pengadilan Negeri. Kepada pemberi advokat untuk memberi bantuan hukum sesuai dengan ketentuan undang-undang

\section{DAFTAR PUSTAKA}

Apriansyah, N. (2020). Problematika Pemberian Bantuan Hukum Struktural dan Nn Struktural Kaitannya dengan Asas Equality Before the Law. Jurnal Ilmiah Kebijakan Hukum, 14(3), 539552.

Bambang Tri Bawono. (2011). Tinjauan Yuridis Hak-Hak Tersangka dalam Pemeriksaan Pendahuluan. Jurnal Hukum, 26(2), 551-570.

Caecilia, W., \& Sondakh, J. (2014). Pemenuhan Hak atas Perumahan yang Layak bagi Masyarakat Miskin di Perkotaan (Suatu Kajian dalam Perspektif Hak Asasi Manusia). Jurnal LPPM Bidang Eko SosBudkum, 1(2), 86-102.

Fauzi, S. I., \& Ningtyas, I. P. (2018). Optimalisasi Pemberian Bantuan Hukum Demi Terwujudnya Access to Law and Justice Bagi Rakyat Miskin. Jurnal Konstitusi, 15(1), 50-72.

Prabowo, A. (2017). Peran Pos Bantuan Hukum (Posbakum) di Pengadilan Agama Bengkulu Kelas I A Berdasarkan Peraturan Mahkamah Agung Republik Indonesia Nomor 1 Tahun 2014. Jurnal Qiyas, 2(2), 197-209.

Rajagukguk, T. (2016). Efektifitas Pos Bantuan Hukum Pengadilan sebagai Pemberi Layanan Bantuan Hukum Cuma-Cuma pada Perkara Pidana pada Pengadilan Negeri Pekanbaru. Jurnal Fakultas Hukum, 3(1), 1-15.

Ramdan, A. (2014). Bantuan Hukum Sebagai Kewajiban Negara untuk Memenuhi Hak Konstitusional Fakir Miskin. Jurnal Konstitusi, 11(2), 85-108.

Samadi, Y. P. (2015). Kewajiban Penyidik dalam Melakukan Pemeriksaan terhadap Tersangka. Lex Crimen, 4(4), 92-99.

Sugiyono. (2013). Metode Penelitian Pendidikan Pendekatan Kuantitatif dan Kualitatif. Alfabeta.

Wadi, F. (2010). Bantuan Hukum dan Implementasi Perlindungan HAM di Indonesia. Jurnal Hukum Islam, 11(1), 21-31. 